\author{
بررسى تغييرات فصلى رطوبت خاك در استان اصفهان \\ با كمك شاخص ماهوارهاى موديس \\ فاطمه هاديان، رضا جعفرى*، حسين بشرى و مصطفى تركش'

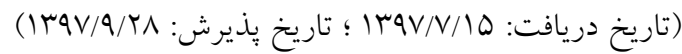

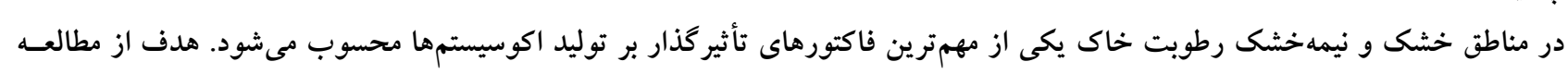

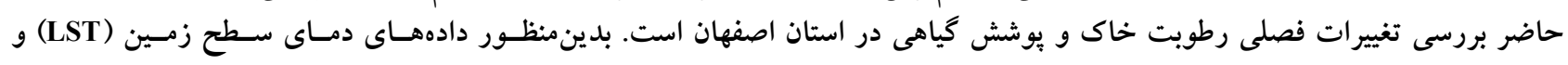

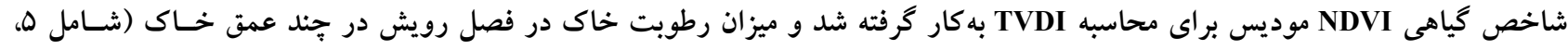

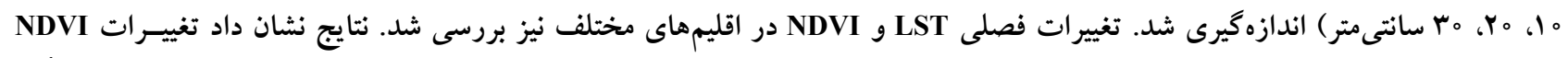

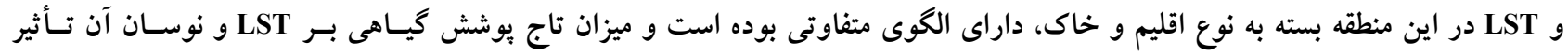

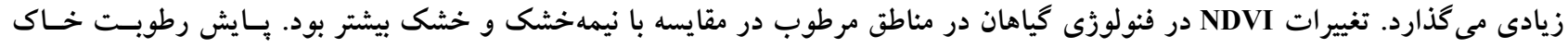

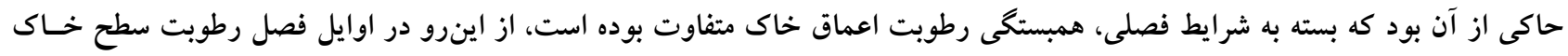

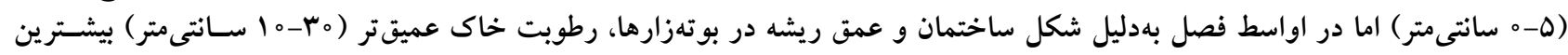

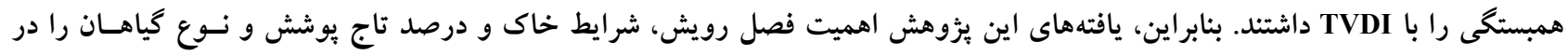

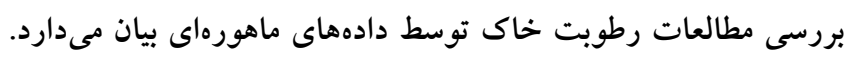

وازههاى كليدى: رطوبت خاك، مقياس فصلى، NDVI،LST، موديس، TVDI 
خشكسالى كو تاهمدت در شرايطى كه كياهان هنوز سـبز هسـتند

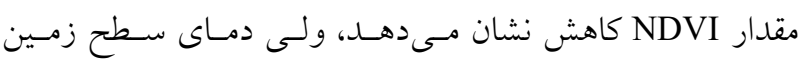
LST (Land Surface Temperature)

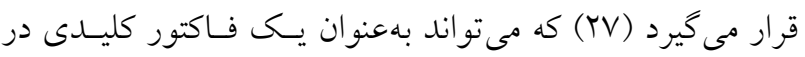
مسائل زئوفيزيكى را در سطوح منطقهاى و جهانى بررسى شـود

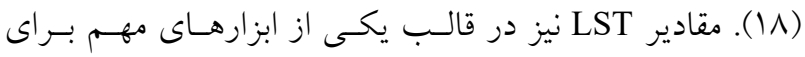

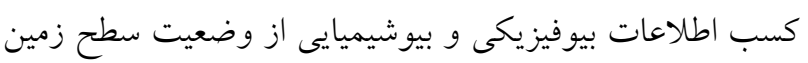
در تحقيقات اقليمشناسى قابل توجه است (V).

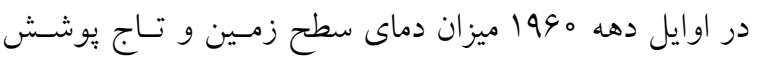

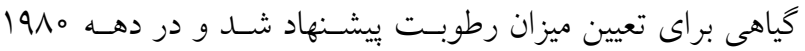

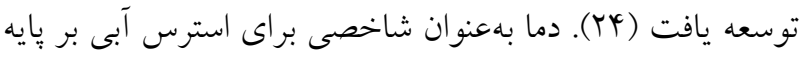

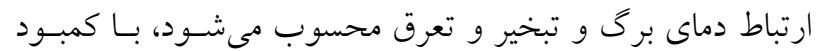

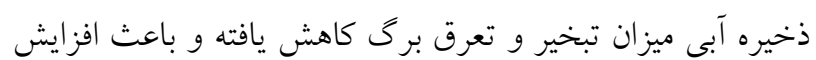

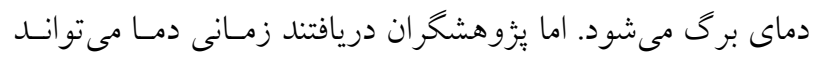

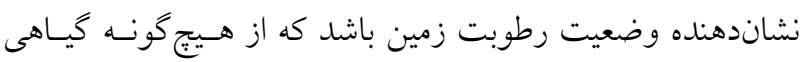

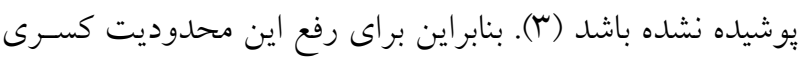

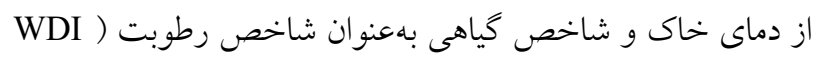
(Water Deficit Index

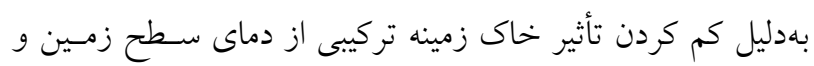
شاخص يوشش گياهى مورد نياز بود. تركيب دما و شاخص كياهى مى تواند اطلاعـات زيسادى در

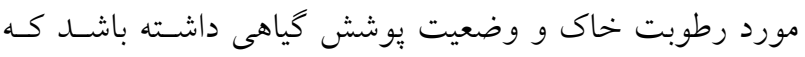

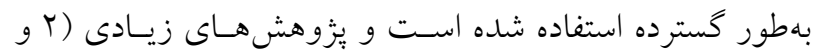

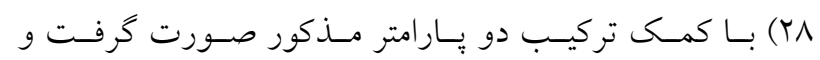

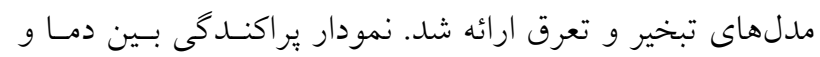

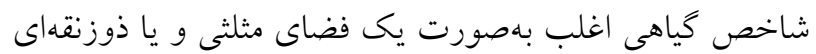
نشان داده مى شود كه بهصورت يكى فضساى NDVI-Ts معرفى لنى

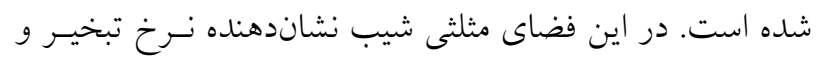
تعرق است كه مى تواند بهمنظور تعيين ميزان دماى هـوا اسـتفاده

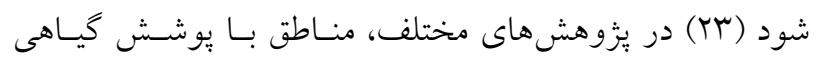

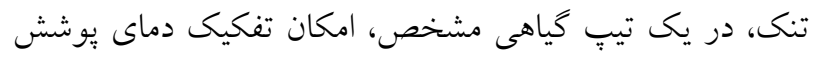

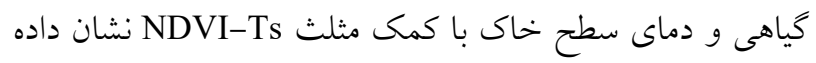

رطوبت زمين يكى از مهمترين متغيرهاى زيستمحيطى اسـت

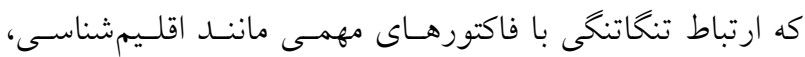

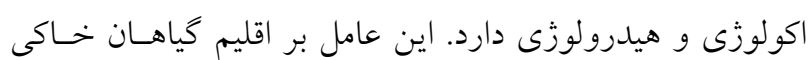

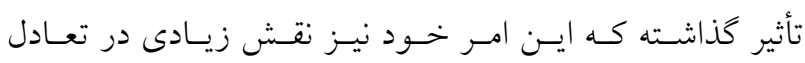
جرخهاى هيدرولوزى و اقليمشناسى مى خذارد (Y).

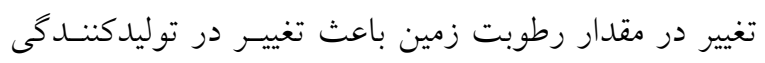

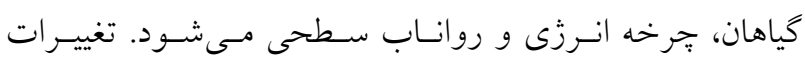

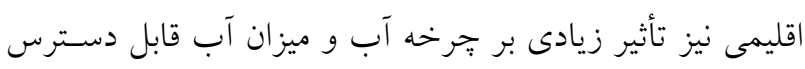

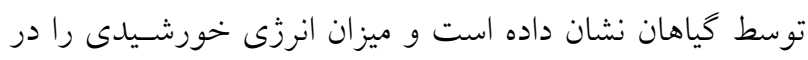

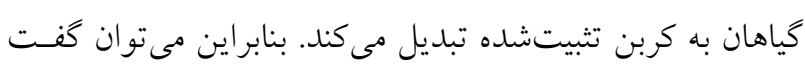

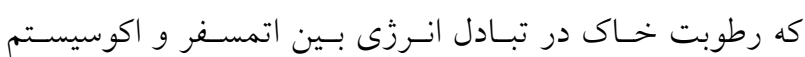
خاكى نقش اساسى دارد (IV).

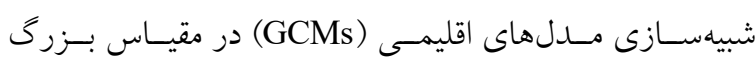
نمىتواند بدون توجه به مدل هيدرولوزى محلى انجام شـود (N).

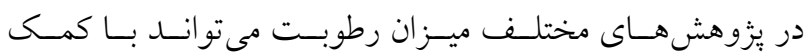

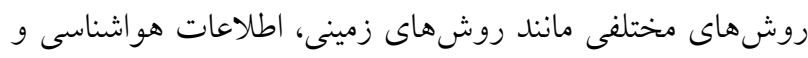

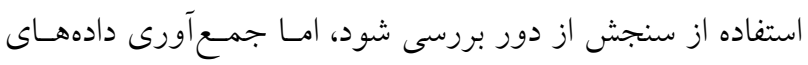

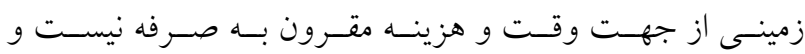

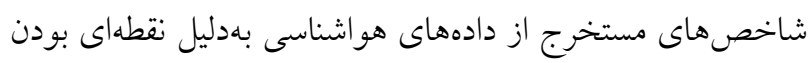

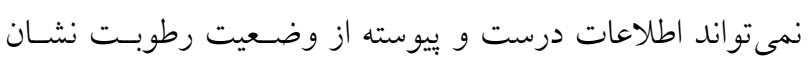

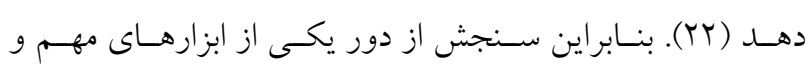

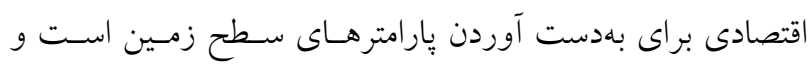

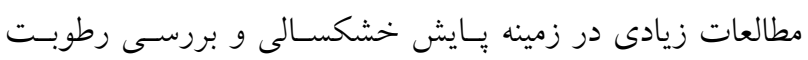

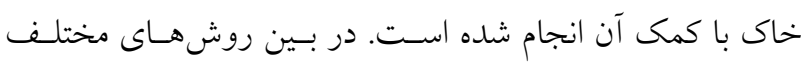
مطالعات سنجش از دور، استفاده سنجش از دور حرارتى بهعنوان

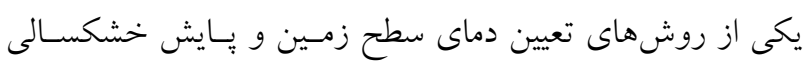

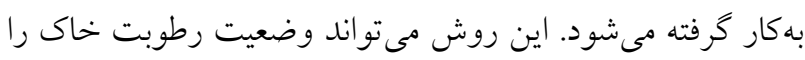
در زمينهاى داراى بوشش گياهى بررسى كند (10).

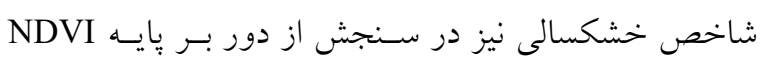
(Normalized difference vegetation index) نشاندهنده استرس آبى در كياهان محسوب مىشود و در زمـان 


\section{مواد و روشها} منطقه مورد مطالعه

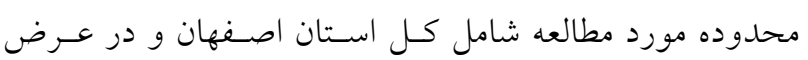

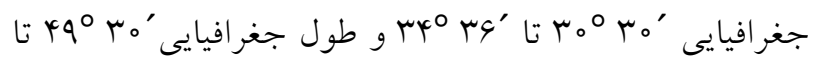

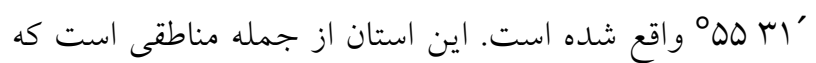
داراى تنوع اقليمى فراوان (مرطوب - فراخشك) است (شكل

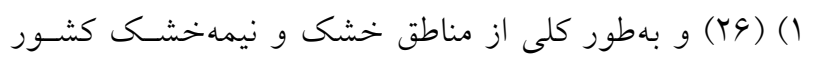
محسوب مىشود. از يك طرف وجود رشتهكوههـاى زاخـرس در قسمت غرب استان مانع نفوذ رطوبت به نواحى مركـزى و شرق استان شـده و از طـرف ديخـر وجــود نــواحى يسـت و كويرى شرق استان، هواى بخش وسيعى از آن را تحست تـأثير خود قرار داده است. ميزان بارش و دما در استان اصفهان تابع وضعيت تويو گر افى منطقه است. در ميان مناطق مختلف استان، خور با ميانخين دماى سالانه 19/0 درجه سانتى گراد، كرمترين و سميرم با متوسـط دمـاى سـالانه /9/ ا درجـهـ سـانتى خـراد، سردترين منطقه استان اصفهان هستند. متوسط بـارش سـاليانه در اين استان در حدود ه Y ا ميلى متر است. سـنخهاى منطقـه شامل كونههاى آتشفشانى، رسوبى و تخريبى و متعلق به زمان

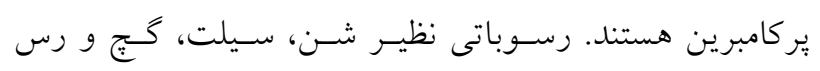
همراه با خاك نيمهعميق با بافت سنخين و سبك ديده مىشود و در اطراف تالاب كاوخونى مواد معدنى نظيـر نمـك وجــود

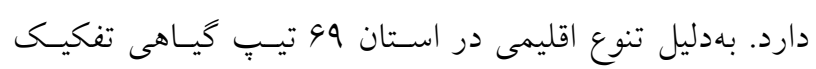
شده است كه بر اساس گونه غالب شامل گونههاى Artemisia Astragalus spp spp Artemisia spp در نواحى بيابانى شرق استان درختخههايى نظيـر Haloxylon در تركيب كياهى وجود دارد (T).

دادههاى ماهوارهاى مورد استفاده بهمنظور تعيين وضـعيت رطوبـت خــاك و گياهـان در مقيـاس فصـلى، دادههـاى سـنجش از دور حرارتـى (تصـاوير ^ روزه مــوديس - LST) و انعكاسـى (تصـاوير 19 روزه مــوديس -
شد (YO). ضمن آنكه مقاومت روزنـه گياهـان و نـرخ تبخيـر و تعرق ارتباط تنخاتنكى با NDVI-Ts داشته است و براى بررسى وضعيت رطوبت خاك استفاده شـده اسـت، بنـابراين شـاخص مذكور در بررسى تغييرات خشكسالى بـهكـار كرفتـه شـد و در مطالعات مختلف (rا و r9) نتايج موفقى مشاهده شـده اسـت. همجنين اسـتفاده از شـاخص هاى رطوبـت خـاك مسـتخرج از دادههاى ماهوارهاى در ريـايش فصـلى (YT) و سـاليانه، رطوبـت خاى در بسيارى از مناطق خشك و نيمهخشى (ه (ا) همبستكى بسيار زيادى با مقادير اندازهذيرى شده زمينى داشـته اسـت كـهـ مىتوان به شاخص TVDI اشاره كرد كه طبق تحقيقات، ضسمن تعيين ميزان رطوبـت موجـود در خـاك، توانسـته اسـت مقــدار

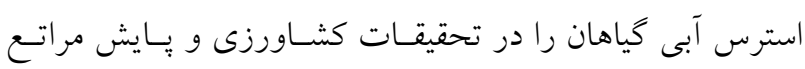
تعيين كند (9). استان اصفهان در مركز ايران قرار كرفته كه بـهدليـل وجــود

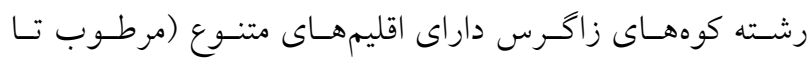
فراخشك) است كه وجود يديده خشكى باعث كاهش رطوبـت رهـ خاك شده است. در شرايط كمآبى و تبخير بالا ميـزان رطوبـت خاى يكى از مهمترين فاكتورهـاى رشـــ در منـاطق خشـى و نيمه خشك محسوب مىشود. از اينرو داشتن اطلاعات كافى در زمينـه رطوبـت خــاك از اساسـى ترين برنامسههاى تحقيقـات زيستمحيطى بهشمار مىرود. در اين گونه مناطق بر اكنش فصلى بارش بسيار نامنظم است و بر دوره فنولوزى كياهان تأثير زيادى دارد. عدم بارش و خشكى خاك در اواخر فصل باعث مى شـود

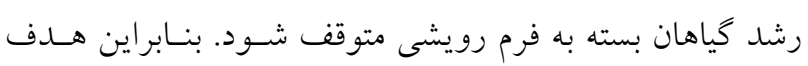
اصلى از اين بززوهش بـايش فصسلى رطوبـت خـاك در اسـتان

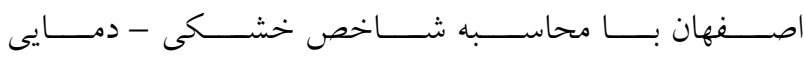
ب) (Temperature - Vegetation Dryness Index) TVDI كمك شاخص كياهى NDVI و LST) و دادههاى زمينى اسـت. ضمن آنكه دادههـاى مـاهواره مـوديس در محاسـبات شـاخص

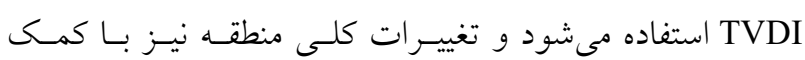
شاخص گياهى NDVI و LST بهتفكيك طبقات اقليمى بررسى مى شود. 

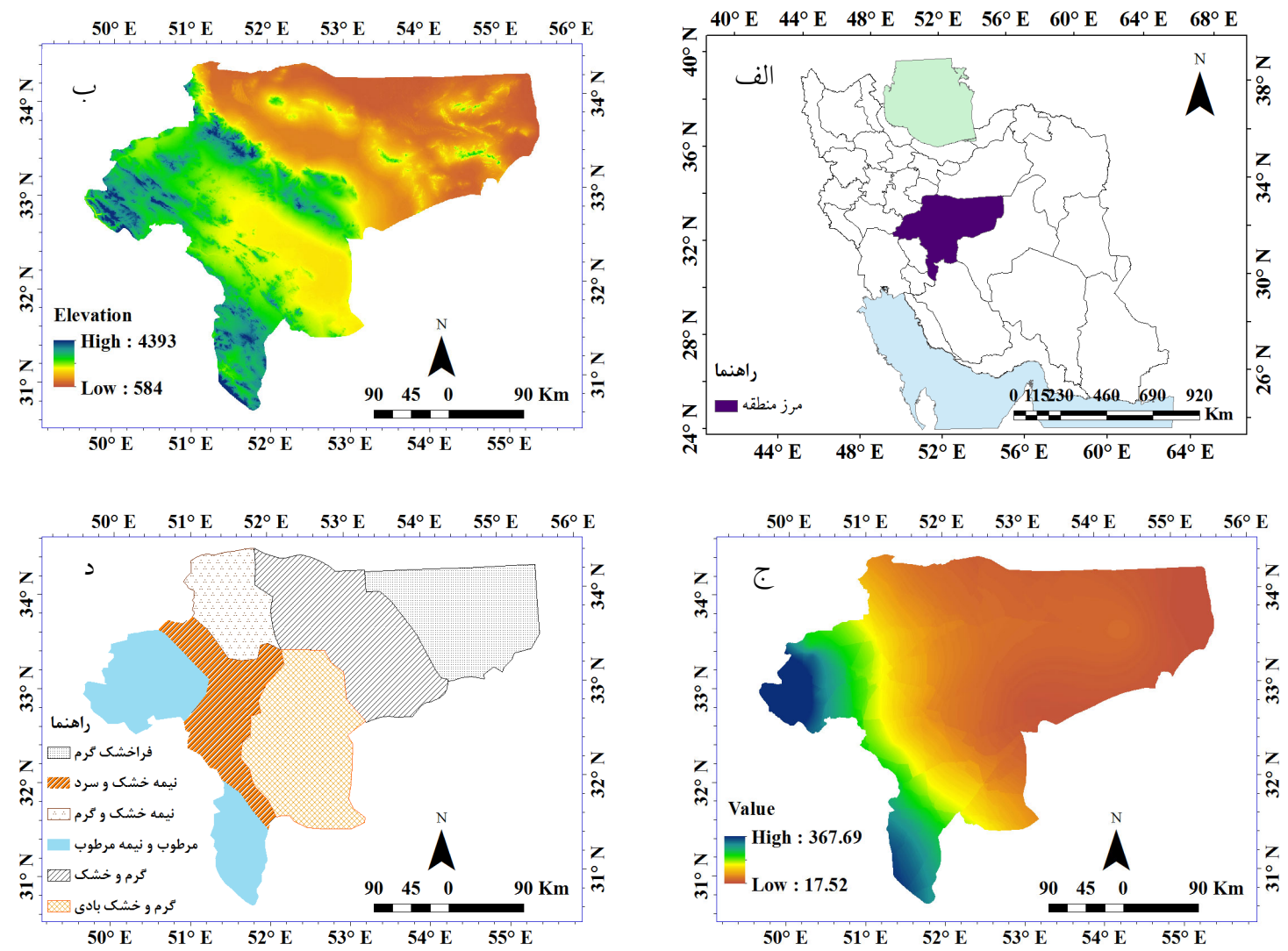

شكل ا. الف) موقعيت منطقه مورد مطالعه، ب) نقشه رقومى ارتفاع (DEM)، ج) بارش متوسط ساليانه و د) طبقهبندى اقليمى (Y\&)

رگرسيون خطى محاسبه شد.

اندازه گيرى رطوبت خاك

بهمنظور بررسى ميزان توليد گياهى، بـ از تفكيك مناطق مشابه

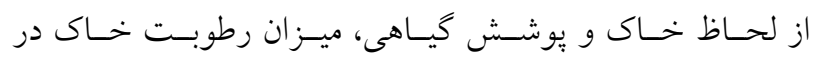
دورههاى مختلف در قالب روش جهار بيكسلى اندازهكيرى شد. در هر دوره زمانى از فصل رويش، تعـداد هو سـايت از منـاطق

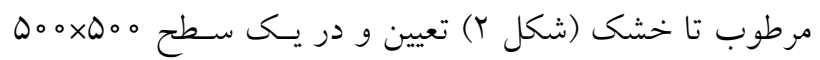
مترمربعى درصد رطوبت خاى در طول فصـل رويسش در يـنج

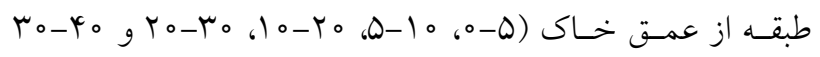
سانتى متر) با كمك دستخاه TDR انــازه كيـرى شــ (شـكل r). تعيين سطح نمونسهــردارى بـا درنظـر گـرفتن وضـوح بيكسـل

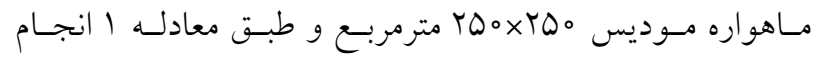
كرفت. در اين معادله A سطح نمونهبردارى، P وضـوح بيكسـل
به كار گرفته شد. با توجه بـه اخــلاف وضـوح مكــانى (NDVI

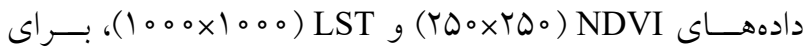
يكسانسازى مقياس نقشههاى دمـا و شـاخص گيـاهى از روش ريزمقياس سازى استفاده شد و اندازه بيكسل كليه تصـاوير LST به •DV متر تغيير يافت و با كمك نرمافزارهـاى سـنجش از دور بيش يردازشها و كاليبراسيون مربوطه صورت كرفت (YI).

NDVI بررسى دماى سطح زمين و شاخص گياهى

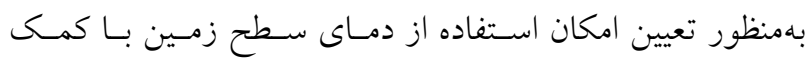
شاخص كياهى NDVI ابتدا مقدار LST و NDVI بـا توجــه بــ نقشه اقليمى استان (شكل 1-د) در هر يـك از اقليمهـاى آب و هو ايى بررسى شد، بنابراين ارزش بِارامترهاى مذكور در هريـى از طبقات اقليمى استخراج و رابطـهـ بـين مقـادير آنهـا (LST) و (NDVI 
$(ب)$

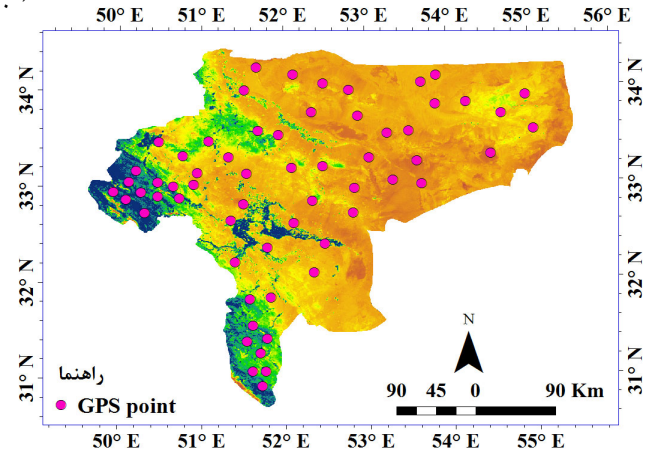

(الف)

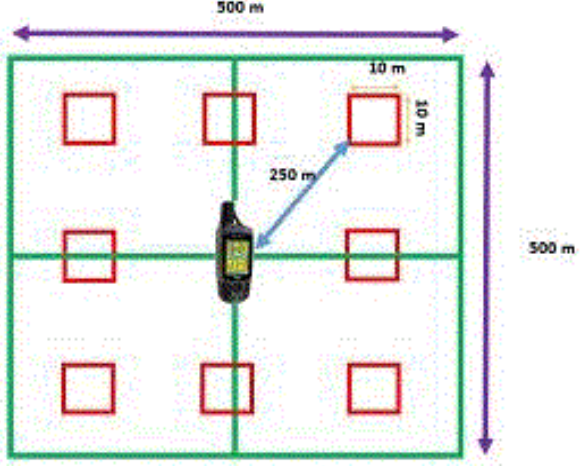

شكل r. الف) روش نمونهبردارى زمينى (رطوبت خاك با دستخاه TDR در بِلاتهاى ه \×10 مترمربعى) و

ب) موقعيت مكانى سايتهاى نمونهبردارى

مرحله آخر شاخص TVDI براى هر تصوير با استفاده از معادله

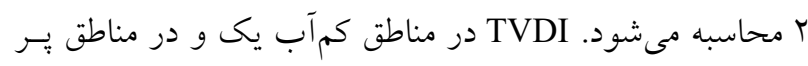

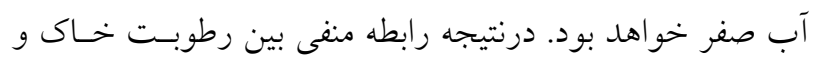
TVDI

$$
\mathrm{VDI}=\frac{\mathrm{LST}-\mathrm{LST}_{\min }}{\mathrm{LST}_{\max }-\mathrm{LST}_{\min }}=\frac{\mathrm{LST}-\mathrm{LST}_{\min }}{\mathrm{a}+\mathrm{b} \times \mathrm{NDVI}-\mathrm{LST}_{\min }}
$$

رابطه بين نقشههاى TVDI توليد شده با مقادير انــازهكيرى شــده

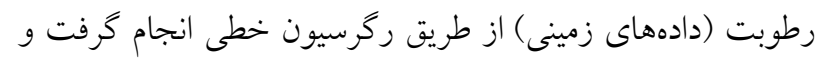

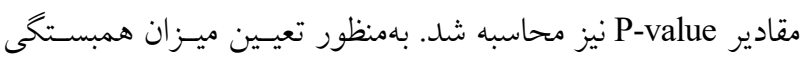

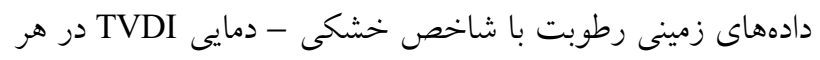
دوره زمانى، در كل استان يكى رابطه كلى در نظر كرفته شد.

نتايج

بررسى تغييرات ساليانه دماى سطح زمين و شاخص گياهى NDVI ميزان دماى سطح زمين در مناطق مختلف اقليمى نشـان داد كـهـ

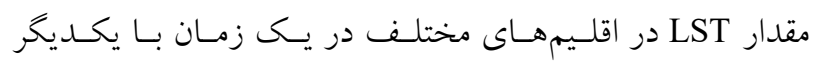

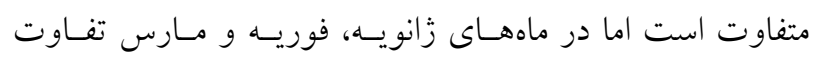

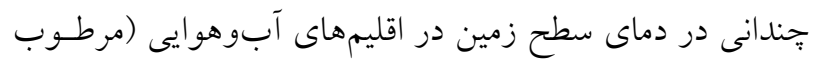

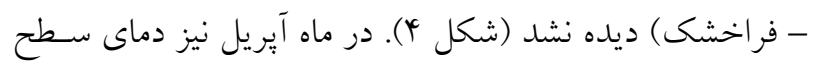
زمين در نقاط مختلف تغيير جندانى نداشت اما در ماه مسى بـين

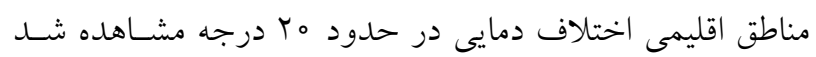

ماهواره برحسب متر و L خطاى مورد قبول است (19). $A(p \times 1+r L)$

Tحاسبه شاخص TVI

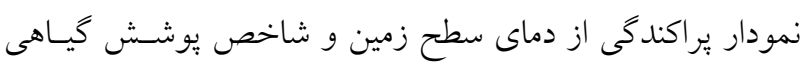

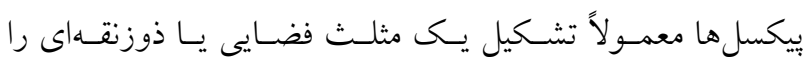

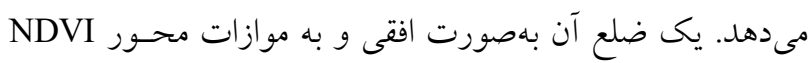

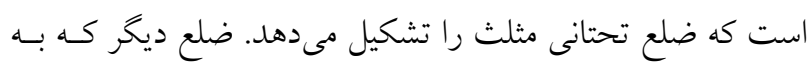

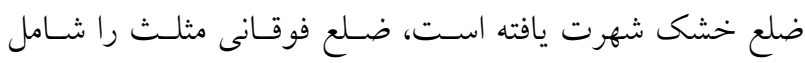

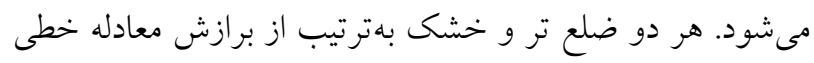

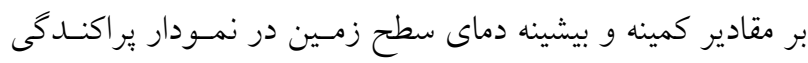

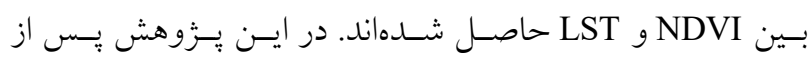

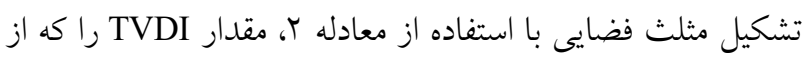
بازه صفر تا يك وجود دارد در طول فصل رويش محاسبه شد. در معادله r، LST دماى سطح بيكسل مورد نظـر و LST

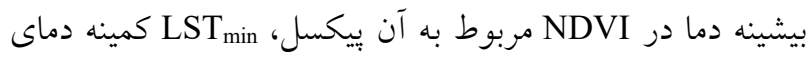

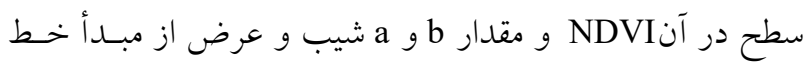

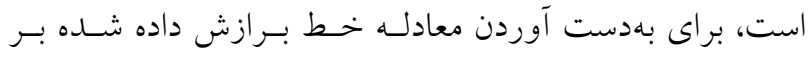
مقـادير بيشـينه ( داراى بيشترين و كمترين دما انتخاب مىشود. بـا رسـم نمـودار

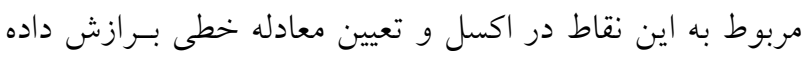
به آنها 


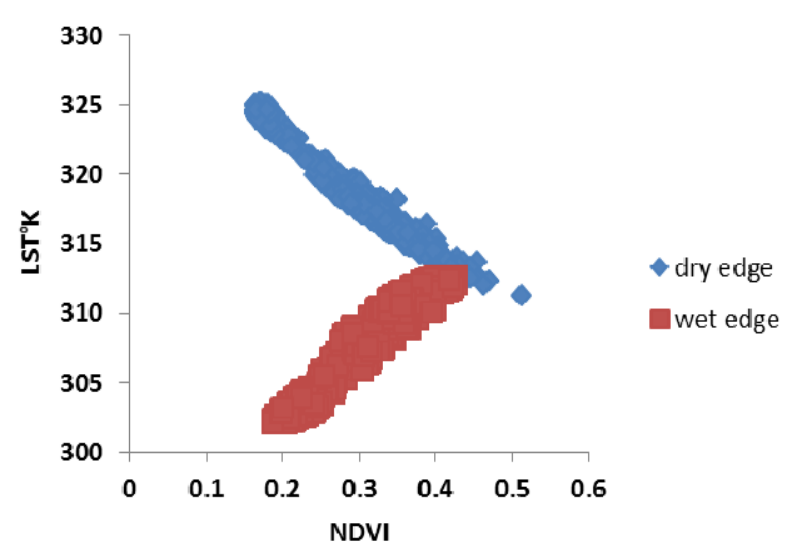

شكل r. نمونهاى از فضاى مثلثى LST-NDVI

مدلسازى ميزان رطوبت با استفاده از شاخص TVDI مدلسازى رطوبت خاك با كمك TVDI نشان داد كه ميزان اين شاخص در طول زمـان و مكــان داراى تغييـرات فــاوان اسـت

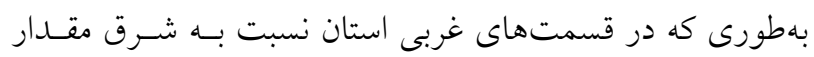

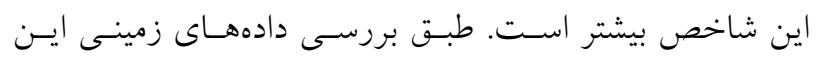

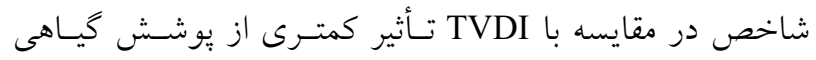
زمين دارد و رطوبت خاك را بهتر نشان مىدهد.

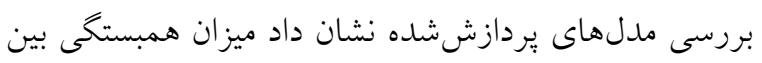

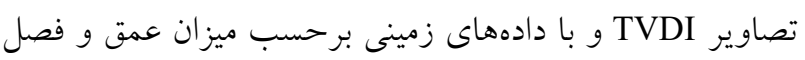

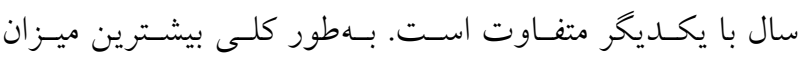

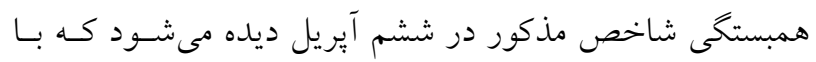

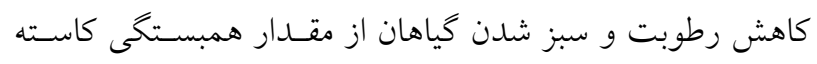

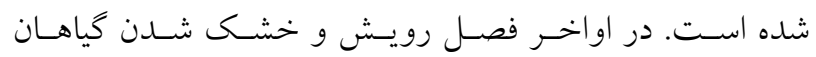

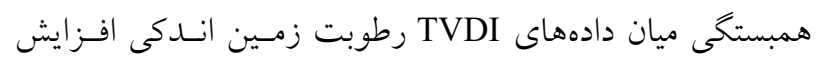

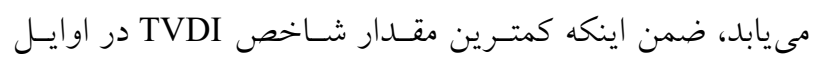

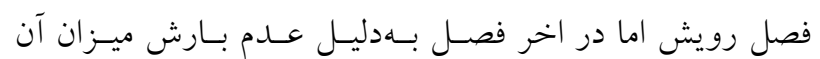
افزايش يافته و در برخى از نقاط استان به يك نزديـى مىشـود

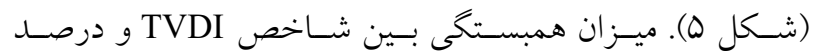
رطوبت حجمى با توجه به ميزان عمق خاك نيز متفاوت اسـت.

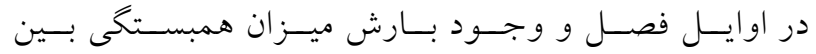
شاخص هاى مذكور و رطوبت زمين در عمق بنج سانتىمترى

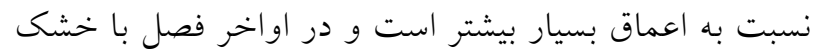

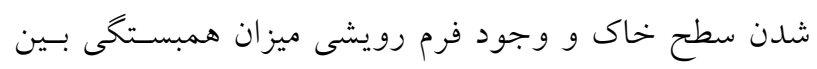

كه در ماههـاى گَرم سـال (زولاى، اكوسـت و سـبتامبر) ايسن تفاوت كاهش مى يابد. مقادير شاخص كياهى NDVI نيز بسته به نوع اقلـيم آبوهـوايى داراى نوسـان اسـت. در اقليمهـاى

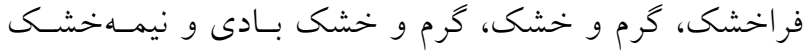
كرم بيشترين مقدار شاخص NDVI در ماه آيريل مشاهده شد اما در اقليمهاى نيمه خشك و سرد و مرطوب و نيمهمرطوب سرد در ماه مى بالاترين ميزان شاخص كيـاهى NDVI وجـود داشت. در ناحيه مرطوب و نيمهمرطوب سرد، تغييرات مقـدار دDVI بود اما در منطقه فراخشك گرم تغييرات ساليانه NDVI نوسان

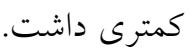

NDVI همبستخى بين دماى سطح زمين و شاخص گياهى

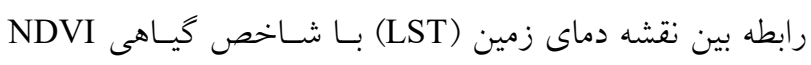

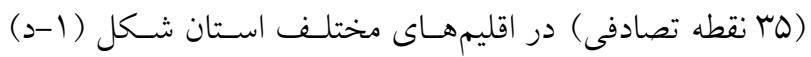
بيانكر آن بود كه رابطه بسيار قوى ميان اين شاخص و نقشهای

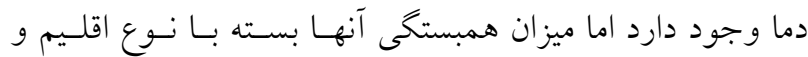
شرايط فصلى مقادير متفاوتى ديده شد. بـهـورى كـه بيشترين همبستكى در ماه مى و كمترين در اكتبر قابـل مشـاهده بـود. در اقليم مرطوب بيشترين و فراخشى كمترين ارتباط ميان دادههاى

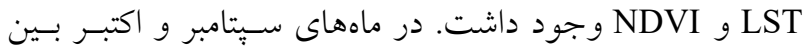
شاخص گياهى NDVI و LST تقريباً مقادير RD يكسـان بودنــ

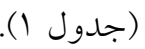



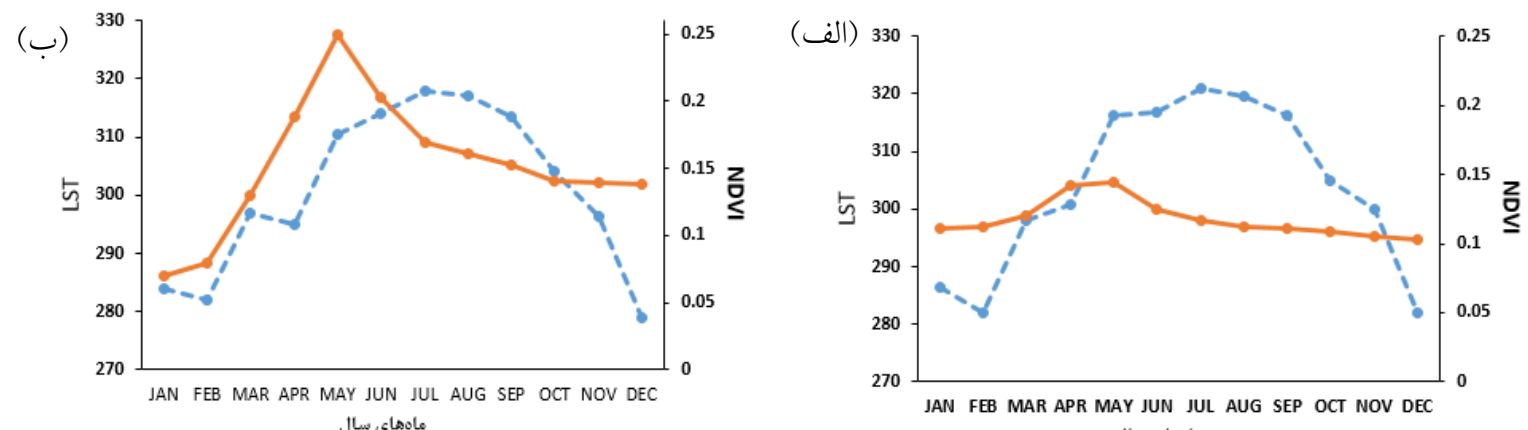

JAN FEB MAR APR MAY JUN JUL AUG SEP OCT NOV DEC

$$
\text { مانهای سال }
$$
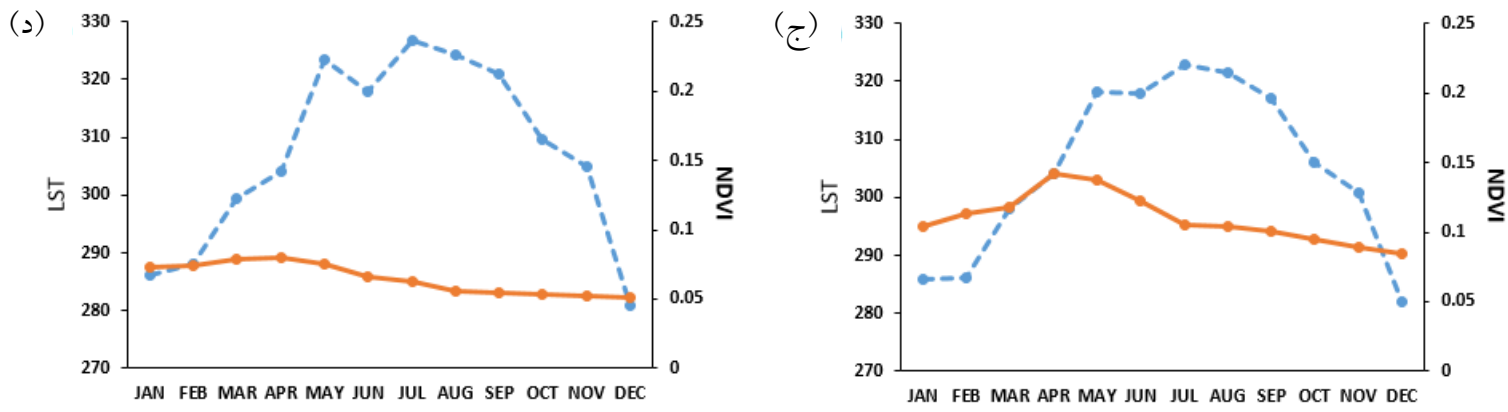
مانهای سال مانهاo

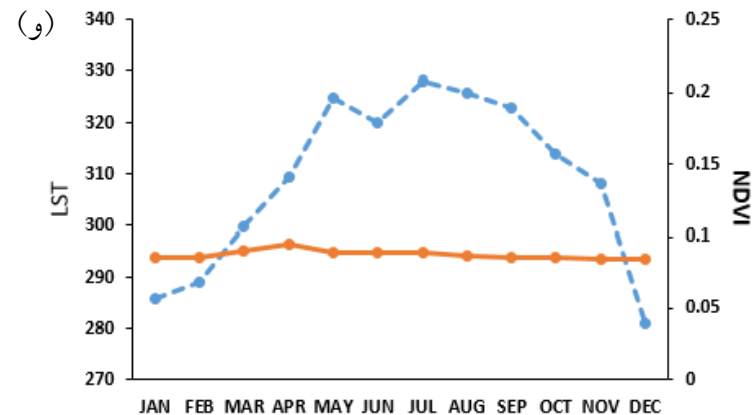

JAN FEB MAR APR MAY JUN JUL AUG SEP OCT NOV DEC

$$
\text { مالى }
$$

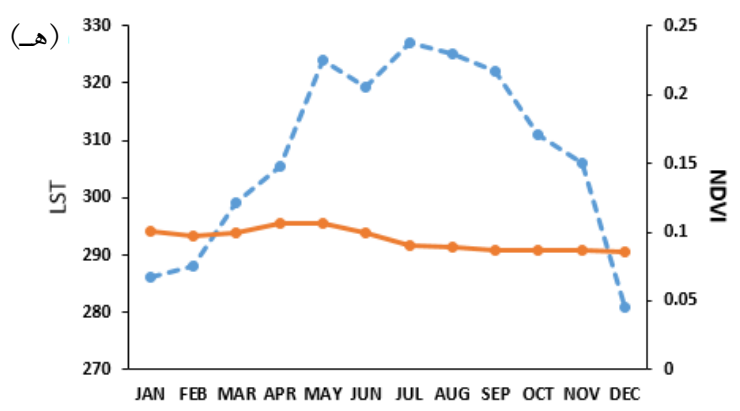

مإى

شكل f. الف) مقادير LST و شاخص گياهى NDVI در اقليم مرطوب و نيمهمرطوب، ب) نيمهخشى و سرد، ج) نيمهخشى و گرم، د) خشك و گرم،

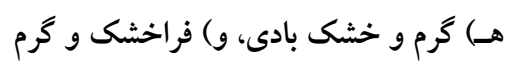

يوشش كياهى باعـث مىشـود تغييـرات دمـاى هــوا در فصـول

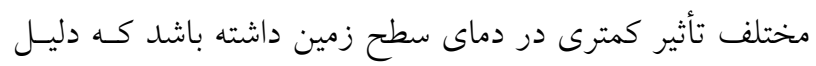

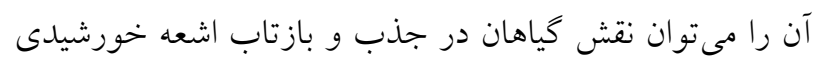

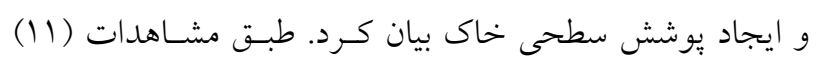

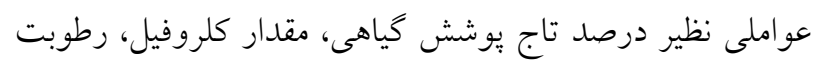

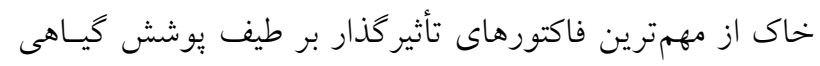

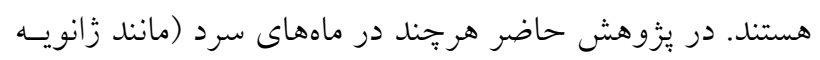

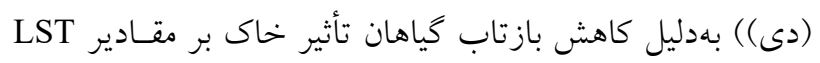

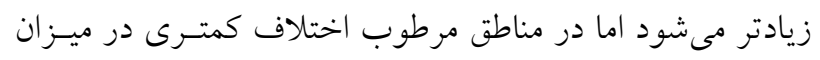

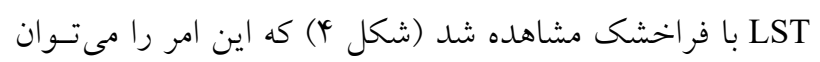

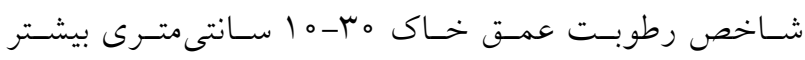

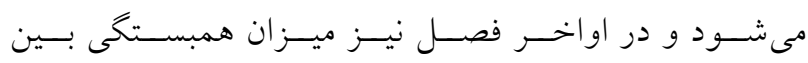

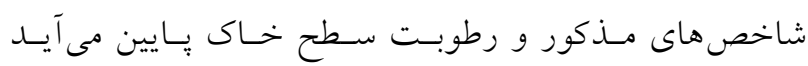

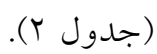
نتــايج بررسـى مقــادير NDVI و LST در مقيــاس فصــلى

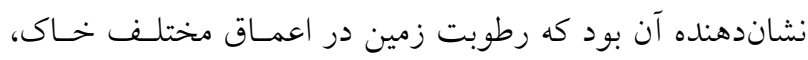
دماى سطح زمين و يوشش كياهى در منطقه مورد مطالعه بستهـ

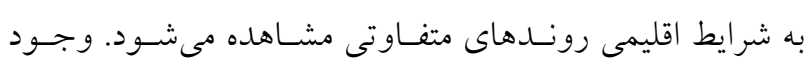


نشريه علوم آب و خاك (علوم و فنون كشاورزى و منابع طبيعى) / سال بيست و سه / ويزٔهنامه سيل و فرسايش خاك / زمستان \هـ|

جدول ا. همبستخى بين دماى هوا و شاخص گياهى NDVI در اقليمهاى مختلف استان اصفهان

\begin{tabular}{|c|c|c|c|c|c|c|c|c|}
\hline مهر & شهريور & 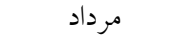 & تير & خ خرداد & ارديبهشت & فروردين & 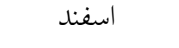 & \\
\hline $0 / 4)(0)$ & $\circ / 4 \mu(\circ)$ & $\circ / 01(0)$ & $\circ / 9 \circ(0)$ & $\circ / \mathrm{N}(\circ)$ & $\circ / 9 Y(\circ)$ & $\circ / \wedge \vee(\circ)$ & $0 / 1 Y(0 / 091)$ & مرطوب ونيمهمرطوب سرد \\
\hline$\circ / T \mu(\circ / \circ \circ \Lambda)$ & $\circ / T \Delta(0 / 004)$ & $\circ / \mu q(\circ)$ & $0 / 49(0)$ &.$/ 09(0)$ & $\circ / \wedge ૬(\circ)$ & $\circ / \Lambda Y(0)$ & $\circ / \Gamma r(\circ / \circ \circ Y)$ & نيمهخشى و سرد \\
\hline.$/ 19(0 / 0 Y Y)$ & $0 / T \circ(0 / 011)$ & $0 / \mu q(0)$ & $0 / 49(0)$ & o/Qr(०) & $\circ / \wedge \mid(\circ)$ & $\circ / V Q(\circ)$ & $\circ / \Gamma q(\circ)$ & نيمهخشك و گرم \\
\hline $0 / 1 Y(0 / 04 r)$ & $0 / 14\left(0 / 0 r^{4}\right)$ & $\circ \circ / T V(\circ / \circ \circ \Psi)$ & $\circ / \mu V(\circ)$ & $\circ / \mathbb{F} V(\circ)$ & $\circ / \vee 9(\circ)$ & $\circ / \mathrm{V} \circ(\circ)$ & $\circ / \mathcal{H}(\circ)$ & كرم و خشك \\
\hline $0 / 10(0 / 099)$ & $0 / 1 Y(0 / 091)$ & $\circ 0 / Y \backslash(0 / 009)$ & $0 / \mu^{\prime}(0 / 001)$ & $0 / \mathcal{F Y}(0)$ & $\circ / V Q(\circ)$ & $0 / 90(0)$ & $\circ / 09(\circ)$ & كرم و خشك بادى \\
\hline$\circ / 1 \circ(\circ / \circ \vee Q)$ & $\circ / 1 Y(\circ / \circ \Delta 9)$ & $0 / T Q(0 / 004)$ & $\circ \circ / T V(\circ / \circ \circ \Psi)$ & $\circ / \mathbb{R}(\circ)$ & $\circ / V I(\circ)$ & $0 / 9 Y(0)$ & $\circ / 9 \circ(0)$ & فراخشى و گرم \\
\hline
\end{tabular}

جدول r. ميزان همبستخى شاخص TVDI و درصد رطوبت حجمى خاك در فصل رويش

\begin{tabular}{|c|c|c|c|c|c|c|c|c|c|}
\hline $11 J U L$ & $25 J U N$ & 9JUN & 24MAY & $8 \mathrm{MAY}$ & 22APR & 6APR & 21MAR & $5 \mathrm{MAR}$ & \\
\hline$-0 / \mu^{\mu}(0)$ & $-0 / Y Y(0)$ & $-0 / \Upsilon 9(0)$ & $-0 / \Psi Q(0)$ & $-\circ / \Delta \Delta(\circ)$ & $-0 / 9 V(0)$ & $-0 / \mathrm{V} \wedge(0)$ & $-0 / 94(0)$ & $-0 / \uparrow \wedge(0)$ & $-\phi$ \\
\hline$-0 / \operatorname{lV}(0)$ & $-0 / Y Y(0)$ & $-\circ / \mu y(\circ)$ & $-\circ / \Gamma \omega(\circ)$ & $-\circ / \mu Y(0)$ & $-0 / \mathbb{A V}(0)$ & $-0 / 90(\circ)$ & $-0 / 01(0)$ & $-\circ / \Gamma \wedge(\circ)$ & ها -ه سانتى متر \\
\hline$-0 / 1 \wedge(0)$ & $-0 / 19(0)$ & $-\circ / \mathscr{A} Q(\circ)$ & $-0 / \mu(0)$ & $-0 / T \mu(0)$ & $-0 / \mu Y(0)$ & $-\circ / \Delta Y(\circ)$ & $-0 / 4 \mid(0)$ & -०/TM(०) & هץ-ه ا سانتى متر \\
\hline$-0 / Y Y(0)$ & $-0 / Y \mu(0)$ & -o/M(०) & $-0 / \mu l(0)$ & $-0 / \backslash \wedge(0)$ & $-0 / Y \backslash(0)$ & $-0 / \mathcal{A r}(0)$ & $-0 / \mu^{\prime}(0)$ & $-0 / Y I(0)$ & مَro-r \\
\hline$-0 / 19(0)$ & $-0 / Y \circ(0)$ & $-0 / Y \mu(0)$ & $-0 / \Upsilon \wedge(0)$ & $-0 / Y_{\circ}(\circ)$ & $-0 / 1 Q(\circ)$ & $-\circ / Y Q(0)$ & $-0 / Y \backslash(0)$ & $-0 / 19(0)$ & $\omega$ \\
\hline
\end{tabular}

كزارش ها نيز بيان كردند (ه) گياهان مناطق خشك و فراخشك

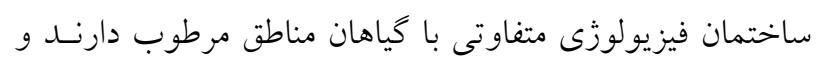
نسبت به تغييرات رطوبت خاك و خشكسالى ساز كار شدهاند.

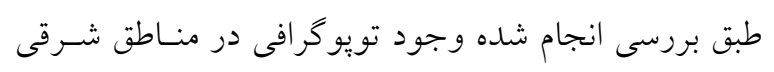
نقش مهمى در تغييرات مكانى دماى هوا دارد. با افزايش ارتفـاع

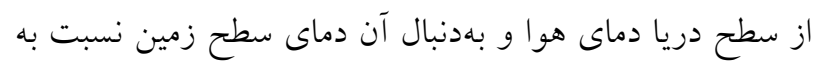
مناطق دشتى كاهش نشان داد (شكل هاى ا و ؟).. در آغاز فصل رويش دما نقش مهمى در جوانهزنى و شروع رشد كياهـان ايفـا مى كند و در مناطق شرقى بهدليل افزايش دما، فنولـوزى گياهـان

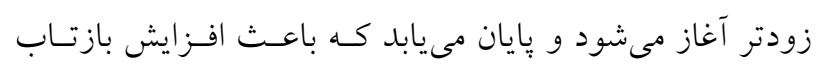

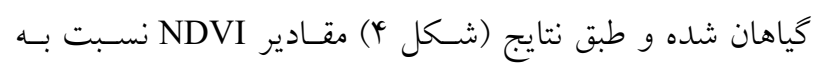
مناطق مرطوب زودتر افزايش و كاهش داشـته اسـت. در اقلـيم فراخشك بهدليل يايين بودن درصد يوشش سـطح زمسين مقـدار

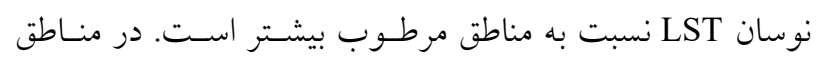

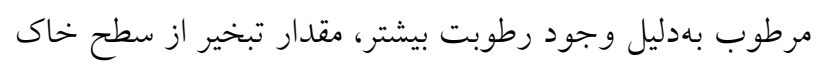
افزايش و LST كاهش مىيابد. با افزايش تراكم بوشـش كيـاهى با فرم رويشى بوتهاى مقدار جـــب رطوبــت از طبقـات زيـرين خاى و فتوسنتز در فصول گرم نسبت به منـاطق شـرقى زيـادتر
تـأثير بافـت خـاك، نفوذيـذيرى و مقـادير لاشـبرى در جـذب

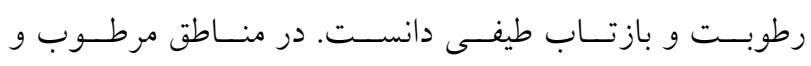
نيمهمرطوب در فصـول سـرد بـهدليـل وجـود يوشـش گيـاهى نزولات آسمانى قدرت نفوذ بيشـترى داشـته و بـهدليـل وجـود

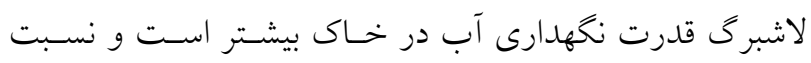
كربن آلى خاك نسبت به مواد معدنى نقش مهمسى در جـــب و

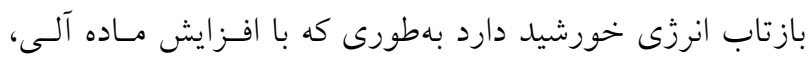

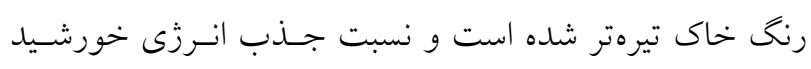
افزايش مىيابد درحالى كه جـذب انـرزى در منـاطق خشـى و فراخشى شرقى بهدليل روشن بـودن خـاك و وجــود لايسههاى كُجى و نمكى كاهش نشان داد، ضمن آنكه در فصول رشد نيـز در مناطق مرطوب و نيمـهمرطـوب تــراكم بوشـش كيـاهى بــر بازتاب طيفى خاى و در نتيجه دماى سطح زمين تـأثير گذاشـته است (Y) و باعث مى شود مقـادير LST در طـول سـال نوسـان كمترى داشته باشند. تغييرات يوشش كياهى در مناطق مرطـوب و نيمـهمرطـوب

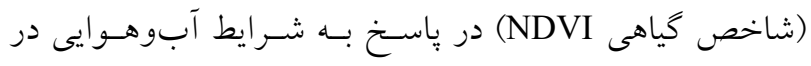
طـول سـال بـا وضـوح بيشـترى مشـاهده مى شـود (شـكل ع). 

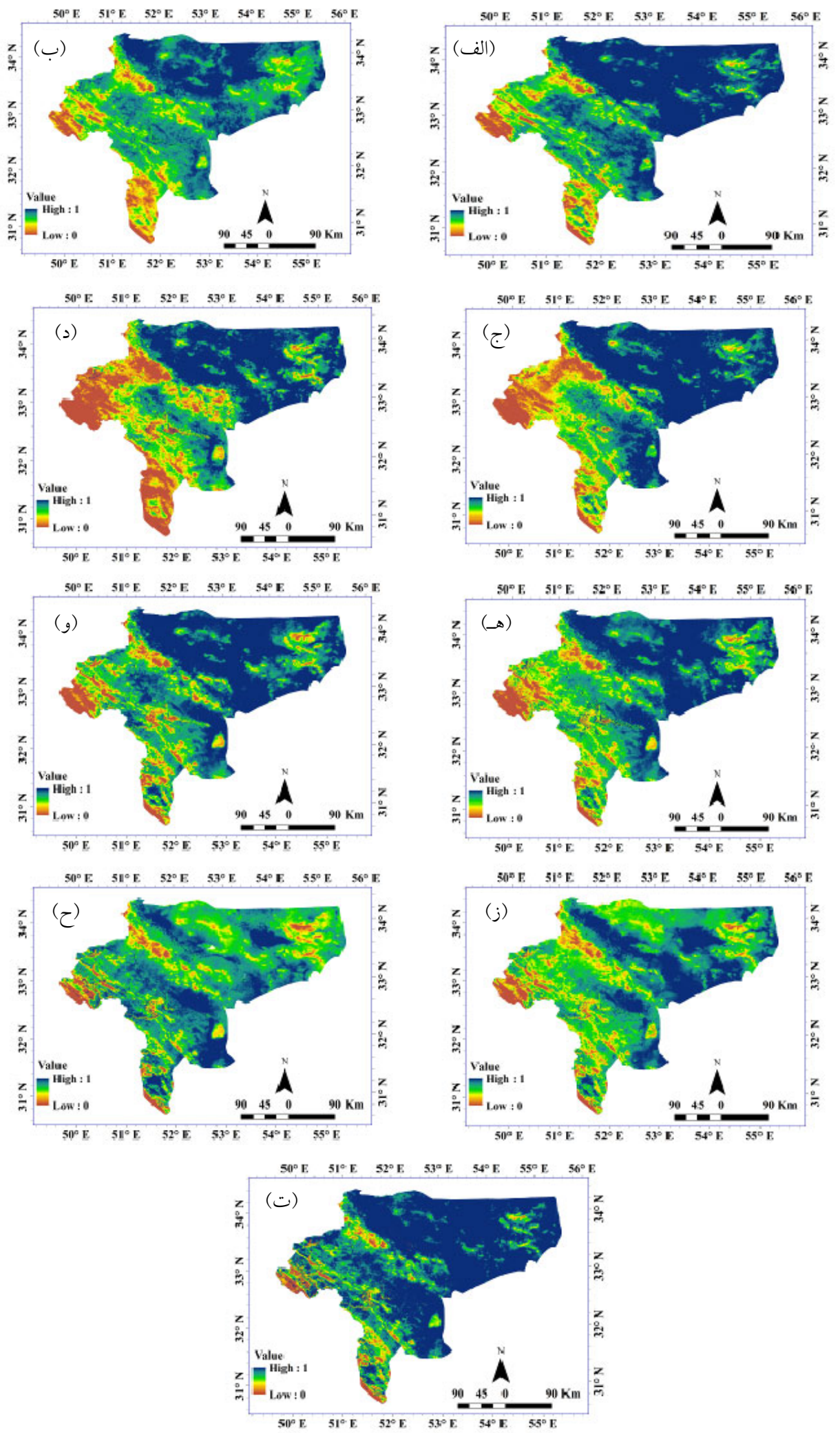

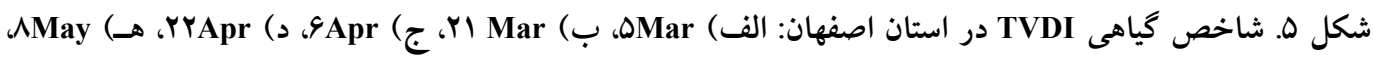

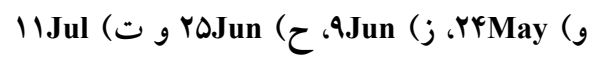


خاك بر شاخص NDVI و LST ميزان تغييرات شاخص TVDI

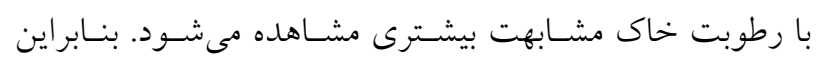

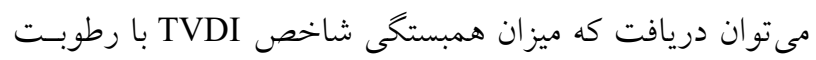

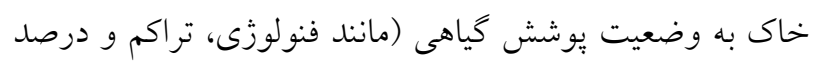

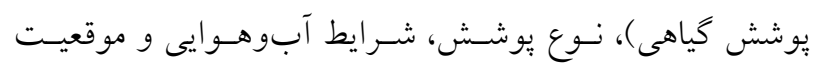
فصلى و جغر افيايى بستكى دارد.

\section{نتيجه گيرى}

بهور كلى مىتوان نتيجه گيرى كرد كـه اسـتفاده از سـنجش از

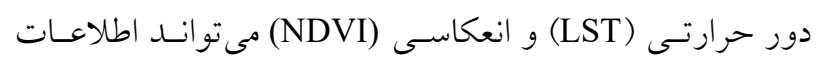

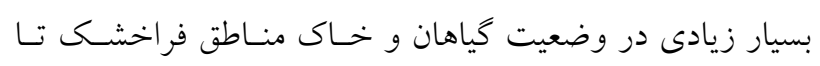

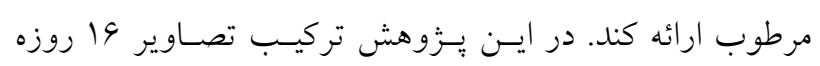

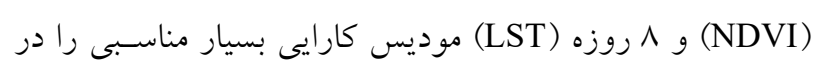

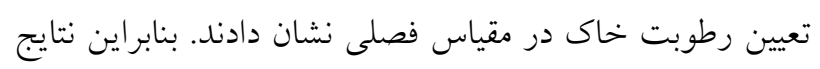

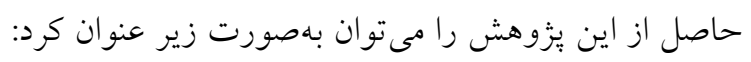

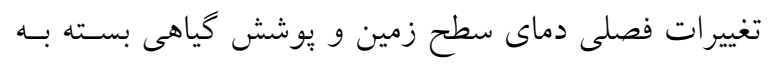

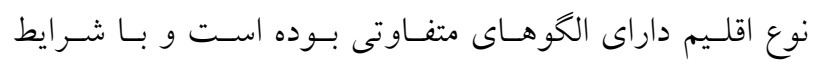

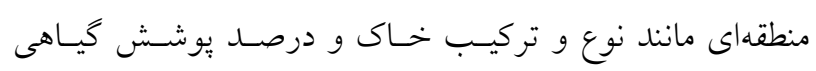
ارتباط نزديكى دارد.

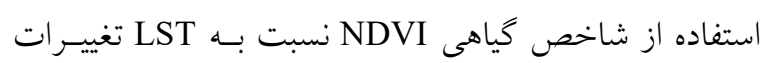

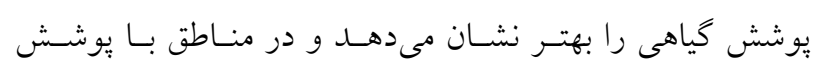

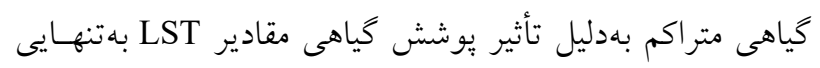

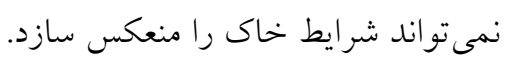

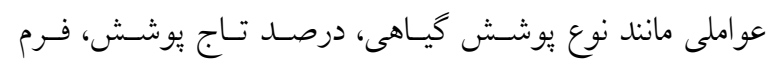

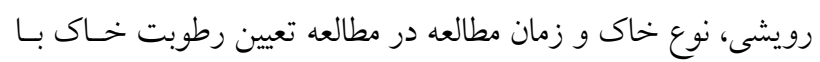
كمك شاخص خشكى - دماى (TVDI) تأثير كذار است. بررسى ميزان رطوبت با كمك TVDI نشان داد با كمك اين

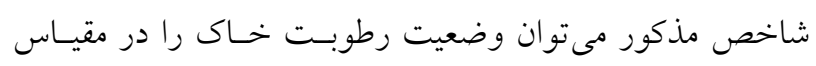

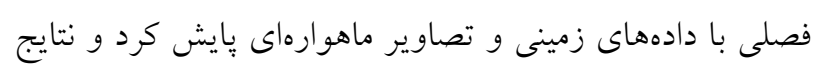

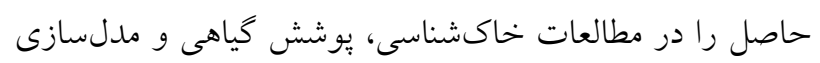
اكو سيستم و شناخت محيط زيست استفاده كرد.
بود و مقــدار شـاخص NDVI افـزايش و LST كـاهش يافـت.

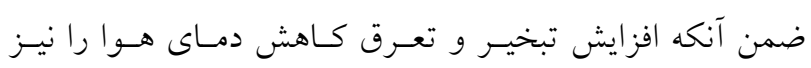
بهدنبال داشت كه در گزارشهاى مختلف نيز تأثير مقدار تبخيـر

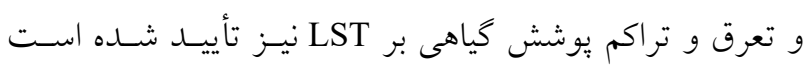
(Yo)

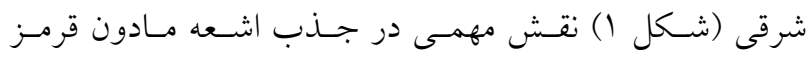
كرمايى داشته و مقادير NDVI در فصول سرد نسبت به منساطق شرقى افزايش بيشترى داشت (شكل \&) ولائ.

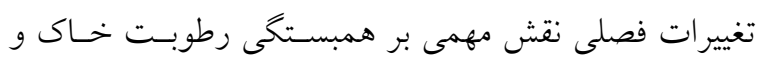

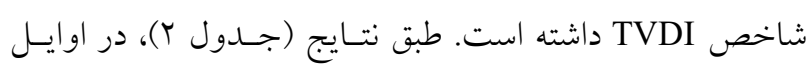
فصل رويش بهدليل تراكم و سبزينكى گياهان تأثير خـاك زمينـه

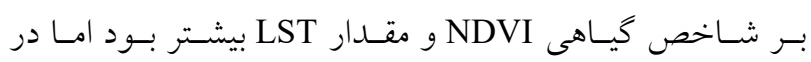

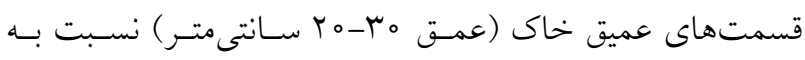

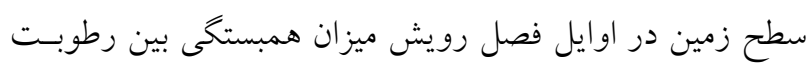

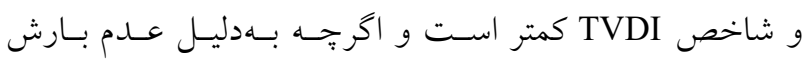
تابستان ارتباط ميان شاخص مذكور و رطوبت ضعيف مسى شـود آنس

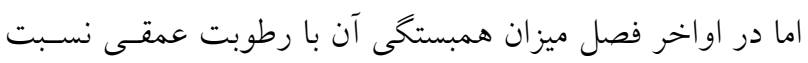

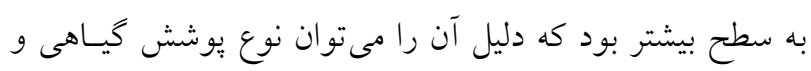

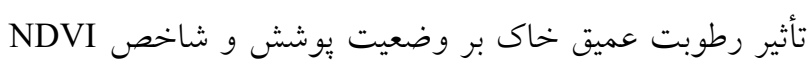

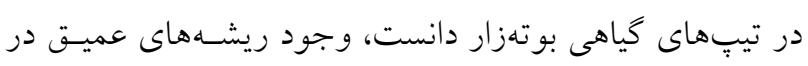

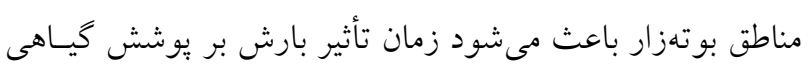

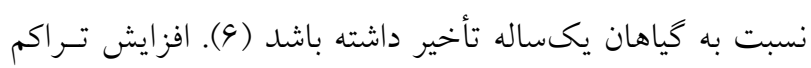

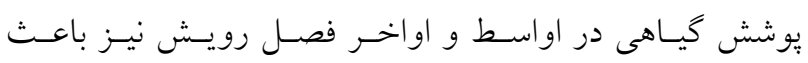

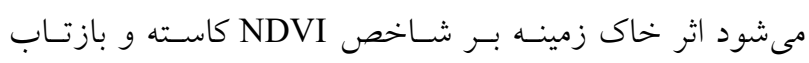

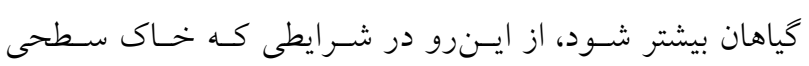

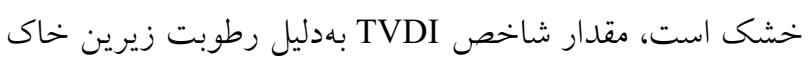

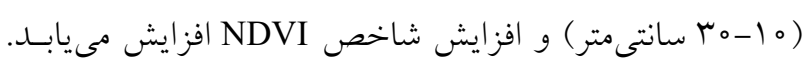

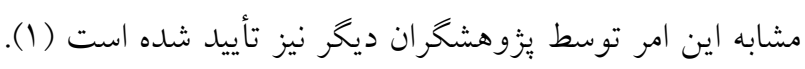
رابطه ميان شاخص TVDI با رطوبت خاك در طول فصل متغير بود كه به تغييرات شاخص NDVI و رابطه فصلى آن بـاخـا خـاك مربوط مىشود. براساس مشاهدات يزوهش حاضر (جدول r ب) و

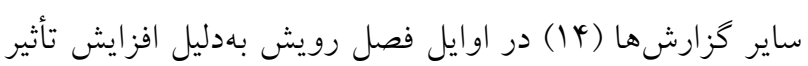




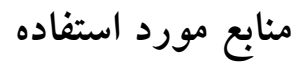

1. Chen, J., C. Wang, H. Jiang, L. Mao and Z. Yu. 2011. Estimating soil moisture using Temperature-Vegetation Dryness Index (TVDI) in the Huang-huai-hai (HHH) plain. International Journal of Remote Sensing 32:1165-1177.

2. Chen, S., L. Zhang, X. Liu, M. Guo and D. She. 2018. The use of SPEI and TVDI to assess temporal-spatial variations in drought conditions in the middle and lower reaches of the yangtze river basin, China. Advances in Meteorology 2018: 1-11.

3. Coll, C., V. Caselles, E. Valor, R. Niclòs, J. M. Sánchez, J. M. Galve and M. Mira. 2007. Temperature and emissivity separation from ASTER data for low spectral contrast surfaces. Remote Sensing of Environment 110: $162-175$.

4. Daughtry, C., C. Walthall, M. Kim, E. B. De Colstoun and J. McMurtrey Iii. 2000. Estimating corn leaf chlorophyll concentration from leaf and canopy reflectance. Remote Sensing of Environment 74: 229-239.

5. Devitt, D. A., J. Piorkowski, S. Smith, J. Cleverly and A. Sala. 1997. Plant water relations of Tamarix ramosissimain response to the imposition and alleviation of soil moisture stress. Journal of Arid Environments 36: 527-540.

6. Golluscio, R., O. Sala and W. Lauenroth. 1998. Differential use of large summer rainfall events by shrubs and grasses : a manipulative experiment in the Patagonian steppe. Oecologia 115: 17-25.

7. Guo, G., Z. Wu, R. Xiao, Y. Chen, X. Liu and X. Zhang. 2015. Impacts of urban biophysical composition on land surface temperature in urban heat island clusters. Landscape and Urban Planning 135: 1-10.

8. Hagemann, S., C. Chen, J. O. Haerter, J. Heinke, D. Gerten and C. Piani. 2011. Impact of a statistical bias correction on the projected hydrological changes obtained from three GCMs and two hydrology models. Journal of Hydrometeorology 12: 556-578.

9. Hazaymeh, K. and Q. K. Hassan. . I V A remote sensing-based agricultural drought indicator and its implementation over a semi-arid region, Jordan. Journal of Arid Land 9: 319-330.

10. Holzman, M. E., R. Rivas and M. C. Piccolo. 2014. Estimating soil moisture and the relationship with crop yield using surface temperature and vegetation index. International Journal of Applied Earth Observation and Geoinformation 28: 181-192.

11. Huete, A., R. Jackson and D. Post. 1985. Spectral response of a plant canopy with different soil backgrounds. Remote Sensing of Environment 17: 37-53.

12. Jafari, R., H. Bashari and M. Tarkesh. 2017. Discriminating and monitoring rangeland condition classes with MODIS NDVI and EVI indices in Iranian arid and semi-arid lands. Arid Land Research and Management 31: 94-110.

13. Khan, J., P. Wang, Y. Xie, L. Wang and L. Li. 2018. Mapping MODIS LST NDVI imagery for drought monitoring in Punjab Pakistan. IEEE Access 6: 19898-19911.

14. Li, X., H. Wang, H. Long, D. Wei and Y. Bao. 2012. A model for the estimation of fractional vegetation cover based on the relationship between vegetation and soil moisture. International Journal of Remote Sensing 33: 3580-3595.

15. Li, Z., Y. Wang, Q. Zhou, J. Wu, J. Peng and H. Chang. 2008. Spatiotemporal variability of land surface moisture based on vegetation and temperature characteristics in Northern Shaanxi Loess Plateau, China. Journal of Arid Environments 72: 974-985.

16. McCoy, R. M. 2005. Field Methods in Remote Sensing. Guilford New York.

17. Melillo, J. M., A. D. McGuire, D. W. Kicklighter, B. Moore, C. J. Vorosmarty, and A. L. Schloss. 1993. Global climate change and terrestrial net primary production. Nature 363: 234-240.

18. Miliaresis, G. C. 2009. Regional thermal and terrain modelling of the Afar Depression from MODIS multi-temporal monthly night LST data. International Journal of Remote Sensing 30: 2429-2436.

19. Moran, M., T. Clarke, Y. Inoue and A. Vidal. 1994. Estimating crop water deficit using the relation between surface-air temperature and spectral vegetation index. Remote Sensing of Environment 49: 246-263.

20. Ottlé, C. and D. Vidal-Madjar. 1994. Assimilation of soil moisture inferred from infrared remote sensing in a hydrological model over the HAPEX-MOBILHY region. Journal of Hydrology 158: 241-264.

21. Pack, S. M. 2009. A MODIS Imagery Toolkit for ArcGIS Explorer.

22. Rahimzadeh-Bajgiran, P., K. Omasa and Y. Shimizu. 2012. Comparative evaluation of the Vegetation Dryness Index (VDI), the Temperature Vegetation Dryness Index (TVDI) and the improved TVDI (iTVDI) for water stress detection in semi-arid regions of Iran. ISPRS Journal of Photogrammetry and Remote Sensing 68: 1-12.

23. Schirmbeck, L. W., D. C. Fontana and J. Schirmbeck. 2018. Two approaches to calculate TVDI in humid subtropical climate of southern Brazil. Scientia Agricola 75: 111-120.

24. Wang, C., S. Qi, Z. Niu and J. Wang. 2004. Evaluating soil moisture status in China using the temperaturevegetation dryness index (TVDI). Canadian Journal of Remote Sensing 30: 671-679.

25. Wang, X., L. Yin, F. Xiao, M. Zhang, L. Liu, Z. Zhou and Y. Ao. 2018. The desertification process in the S ilk R oad E conomic B elt in the past 15 years : A study using MODIS data and GIS analysis. Geological Journal 53: $322-331$ 
26. Yaghmaei, L., S. Soltani and M. Khodagholi. 2009. Bioclimatic classification of Isfahan province using multivariate statistical methods. International Journal of Climatology 29: 1850-1861.

27. Yang, S. H., S. D. Lee, Y. J. Kim and J. Y. Rhee. 2013. Greenhouse heating and cooling with a heat pump system using surplus air and underground water thermal energy. Engineering in Agriculture, Environment and Food 6: 86-91.

28. Zhang, X., H. Zhao and J. Yang. 2018. Spatial downscaling of land surface temperature in combination with TVDI and elevation. International Journal of Remote Sensing 40(5-6):1-12.

29. Zormand, S., R. Jafari and S. S. Koupaei. 2017. Assessment of PDI, MPDI and TVDI drought indices derived from MODIS Aqua/Terra Level 1B data in natural lands. Natural Hazards 86: 757-777. 


\title{
Seasonal Evaluation of Soil Moisture Changes in Isfahan Province Using Temperature Vegetation Dryness Index (TVDI)
}

\author{
F. Hadian, R. Jafari ${ }^{*}$, H. Bashari and M. Tarkesh ${ }^{1}$
}

(Received: October 7-2018; Accepted: December 19-2018)

\begin{abstract}
Soil moisture is one of the most important factors that can affect productivity in ecosystems in arid and semiarid regions. The aim of this study was to investigate soil moisture and vegetation changes in the Isfahan province at the seasonal scale. For this purpose, MODIS Land Surface Temperature (LST) and NDVI data were used to calculate the TVDI index, and the rate of soil moisture content was also measured at several soil depths including $5,10,20,30 \mathrm{~cm}$. in the growing season. Seasonal changes of LST and NDVI indices were also studied in different climate regions ranging from humid to hyperarid. The results showed that the changes in NDVI and LST in this region were different, depending on the climate type and soil conditions; the LST and its changes mostly depended on the amount of vegetation cover NDVI changes based on the plant phenology in humid regions, which was were greater than that in arid and semi-arid climates. Soil moisture monitoring indicated that the relationships between TDVI and different soil depths varied based on the seasonal conditions. In the early growing season, the soil moisture at the depth of $0-5 \mathrm{~cm}$ had a higher correlation with TVDI, but in the middle of growing season, the deeper soil moisture $(10-30 \mathrm{~cm})$ showed the highest correlation. Therefore, the findings of this research indicated the importance of the growing season, soil conditions and vegetation percentage and types in the soil moisture studies by using satellite data.
\end{abstract}

Keywords: Soil moisture, Seasonal scale, LST, NDVI, MODIS, TVDI

1. Department of Rangeland and Watershed Management, Faculty of Natural Resources, Isfahan University of Technology, Isfahan, Iran.

*: Corresponding Author, Email: reza.jafari@cc.iut.ac.ir 